\title{
特集 グリオーマ治療の現状と展望
}

\section{テモゾロミド導入後のグリオーマ薬物療法}

\author{
廣瀬 雄一.1) \\ 1）藤田保健衛生大学脳神経外科
}

\section{Management of Malignant Glioma in the Temozolomide Era}

\author{
Yuichi Hirose, M.D. ${ }^{1)}$ \\ 1) Department of Neurosurgery, Fujita Health University
}

With the introduction of temozolomide (TMZ), a drug treatment for malignant gliomas has been developed and the importance of chemotherapy has been validated. Nonetheless, these tumors are still incurable, and many issues remain to be solved. Recent advances in tumor genetics have enabled us to better predict each patient's prognosis, and, especially in the TMZ era, methylation of the $\mathrm{O}^{6}$-methylguanine-DNA methyltransferase (MGMT) promoter has been thoroughly investigated. This DNA repair enzyme catalyzes the $\mathrm{O}^{6}$-methylguanine that TMZ creates and theoretically promotes TMZ resistance, and clinical studies have revealed that MGMT-proficient gliomas indeed showed a poorer prognosis. Thus many studies were carried out in an effort to inhibit MGMT in gliomas and to overcome TMZ resistance, but unfortunately, none have yielded a successful result, which leads to the conclusion that TMZ-resistance is not promoted solely by MGMT. Since medical treatment for malignant gliomas using DNA damaging agents could show limited efficacy, a new concept of molecular-targeted therapy has been developed. However, clinical studies using various molecular-targeted compounds did not make remarkable improvement in patients' prognosis either. New problems that have emerged from various clinical studies are discussed in this text to open novel prospects for medical treatment of malignant gliomas.

(Received September 26, 2011; accepted October 4, 2011)

Key words : temozolomide, drug resistance, molecular targeted therapy

Jpn J Neurosurg（Tokyo）21:200-206, 2012

\section{はじめに}

一般的に外科的切除の対象になる悪性腫瘍の治療の第 一段階は腫瘍の可及的な切除であり，悪性グリオーマの 治療も例外ではない。しかし, 脳という臓器は広範な切 除が困難であり，しかも悪性グリオーマは浸潤性に発育 するため, 手術による根治は困難である。このことは手 術中 MRI 検査や科学的蛍光法などの技術支援を駆使し ながら顕微鏡下手術が発達した現在においても未解決の 問題であり, 肉眼所見はもちろん, 精密な画像検査や化

\begin{abstract}
学標識によっても正常所見を示す部分に腫瘍細胞が存在 することは周知のとおりである。したがって悪性グリ オーマは理論的に完全切除が期待できない腫瘍であり, 有効な補助療法を行わずして腫瘍再発を阻止することは できない.すなわち覀性グリオーマの治療においては, 外科療法に引き続いて化学療法, 放射線療法を中心とし た補助療法を行うことが不可欠であり，いずれの分野に おいても治療効果改善の試みが続けられてきた。このう ち化学療法に関しては DNA エチル化剂であるニトロソ ウレア製剤が中心に使われたものの，膠芽腫を含めたア
\end{abstract}

連絡先：廣瀬雄一, $\overline{\mathbf{T}} 470-1192$ 豊明市沓掛町田楽厅窪 1-98 藤田保健衛生大学脳神経外科

Address reprint requests to: Yuichi Hirose, M.D., Department of Neurosurgery, Fujita Health University, 1-98 Dengakugakubo, Kutsukake-cho, Toyoake-shi, Aichi 470-1192, Japan 
ストロサイト系神経膠腫の治療成績に関しては長期にわ たって大きな改善はなかった。そうした中で，この分野 での大きな進歩と言えるのがテモゾロミド（temozolomide：TMZ) ${ }^{16)}$ であり, 特に経口投与が可能な点や大きな副 作用を示すことが少ない点は，悪性グリオーマ症例に対 する維持化学療法を行うことを比較的容易ならしめ, 治 療継続中の QOL 維持の点での有用性は特筆に値すると 思われる ${ }^{16)}$. しかしながら, TMZによる化学療法は決し て腫腸根治を約束するものではなく, 大半の症例では腫 瘍が再発するため，これに対する新たな治療戦略の確立 が必要である。本稿では現在最も重要な脳腫隍治療薬剤 である TMZ および新規薬剤に関する臨床研究や生物学 的知見を紹介しながら，悪性グリオーマに対する化学療 法の問題点と今後の展望を理解寸る参考としたい.

\section{テモゾロミドによる 悪性グリオーマ治療成績の現状}

\section{1 治療効果}

2005 年の Stupp らの報告 ${ }^{23)}$ は, 初発膠芽腫に対する $\mathrm{TMZ}$ と放射線治療の同期療法が予後改善をもたらすこ とを示し，以後はほぼ全世界で彼らの提唱した治療法が 踏襲されていると言っても過言ではない。この臨床研究 は約 600 人の治験参加者から得たデー夕に基づいたも のであるが, 腫瘍摘出術後の膠芽腫患者を「放射線治療」 群と「放射線治療+TMZ 投与」群に分け，TMZ の放射 線治療への上乗せ効果を検討したものである，放射線治 療は 1 回照射 2 グレイで 1 週間に 5 回, 計 60 グレイの 照射を行う.TMZの投与は「放射線治療中」に $75 \mathrm{mg} / \mathrm{m}^{2} /$ 日であり，何らかの理由によって放射線治療期間が延び た場合でも TMZ 投与は 49 日を超えないことになって いる。また，放射線治療終了後は 28 日ごとに $150 \mathrm{mg} /$ $\mathrm{m}^{2} /$ 日 (初回), または $200 \mathrm{mg} / \mathrm{m}^{2} /$ 日 (2 回目以降) の 5 日間連続投与を最大 6 回行った. TMZ 投与量法は, 理 論的に耐性にかかわる DNA 修復醳素である $\mathrm{O}^{6}$-methylguanine-DNA methyltransferase（MGMT, 後述) の不活 化（末梢血中の単核球での活性を測定して評価）に十分 な量として設定された．結果として補助療法として放射 線治療のみ行った群で平均生存期間が 12.1 力月であっ たのに対して, TMZ を加えた群では 14.6 力月であり, 2 年生存率が前者で $10.4 \%$ であったのに対して, 後者で は 26.5\%であった. TMZ が他の化学療法剤を比較刘象と してその効果を検討されたわけではなく，あくまでも放 射線治療に対する上乗せ効果の有無を検討されたという ことは，その時点では膠芽腫に対する薬剤療法が有効で
あると考えられていなかったことを示している。わずか 2.5 力月の生命予後延長効果を示す薬剤がその後の短期 間のうちに多くの国で使われるようになったことも，膠 芽腫の薬剤治療の困難性が臨床の場で大きな問題であっ たことを示している，その後，同グループは，TMZによ る膠芽腫の治療成績について長期的なフォローアップに より得られたデー夕も報告している ${ }^{24)}$ ，その内容は基本 的には先の研究で報告された内容の確認になっている が, 興味深いことには「放射線治療」群と「放射線治療十 $\mathrm{TMZ}$ 投与」群との間の生命予後の差が肉眼的腫啅全摘出 の場合には，それぞれ 14.2 力月と 18.8 力月で 4.6 力月 の延長であったのに対して，腫瘍生検の場合には，それ ぞれ 7.8 力月と 9.4 力月で 1.6 力月の延長しかみられな かったことである。このような TMZ の効果の差は，年 噛など他の因子によっても影響を受けることが報告され て㧍り, 改めて膠芽腫が集学的に治療されなくてはなら ない疾患であることを示している。

\section{2 薬㨈感受性}

TMZ の臨床導入は悪性グリオーマの治療に大きな進 歩をもたらしたが，腫愓の根治にまで至ることは現状で は期待できず，しかも治療初期には効果が認められても 腫瘍はやがて発育を再開し, TMZにも反応しなくなる. すなわち薬戍耐性が大きな問題であることは他の化学療 法剤の場合と同様であり，その機序を理解することは， 治療反応性の予測ひいては治療法の選択のうえで重要で ある。そうした意味で TMZ 化学療法を考える時に重要 と考元られるのが, DNA 修復酵素 $\mathrm{O}^{6}$-methylguanineDNA methyltransferase（MGMT）である. MGMT につ

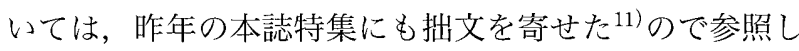
ていただきたいが，TMZによってグアニンの $0^{6}$ 位にメ チル化が起きた DNA からメチル基を除去する醭素であ る. $0^{6}$ チル化グアニン自体には細胞毒性がないため, TMZ によって DNA 修飾が起きても腫瘍細胞は即座に 死なない. TMZによる抗腫瘍作用が現れるためには $0^{6}$ メチル化グアニンの形成に引き続いてグアニン：チミン (GT) ミスマッチが生じることが必要で, GT ミスマッチ が細胞内に備少る DNA ミスマッチ修復機構 (DNA mismatch repair system, MMR）を活性化し，二次的に DNA 二重鎖断裂を惹起して細胞死を誘導すると考えられてい る.MGMT は基質であるメチル化グアニンからメチル基 を除去すると細胞内で分解されるので，大量のメチル化 グアニンが形成されればMGMT は枯渴するはずである が，MGMT のタンパク合成は非常に速いため，常に DNA メチル化剤を投与し続けなければ，いずれ合成され 
たMGMTによりDNA は修復される。すなわち MGMT を発現する腫場においては TMZ の効果は一時的あるい は無効である ${ }^{9)}$.また MGMT はメチル化グアニンだけで はなくエチル化グアニンも修復することから, DNA 中の グアニンをエチル化するニトロソウレア製戍に関しても 薬刘耐性の原因になりうる。したがって，あまり効果の 芳しくないグリオーマの化学療法についての研究におい ては，MGMT が研究対象となることは TMZ 導入以前か ら行われてきたが, TMZがグリオーマに対する中心的化 学療法羭となるに至って，ますますその重要性が注目さ れるようになった。

そもそも前述の Stupp らの TMZ 投与スケジュール は，末梢血中の単核球における MGMTを枯渴させるこ とを指標として考案されたものであるが，彼らのグルー プはさらに MGMT 発現状況が TMZ による治療効果と 相関することを示した ${ }^{8)}$. 彼らの行った MGMT 発現の解 析は，タンパク量や酵素活性の測定ではなく，プロモー ター領域中の $\mathrm{CpG}$ island と呼ばれる部分のメチル化で あるが，これは同部のメチル化により MGMT タンパク の発現が抑制されることが知られていたことによるもの である。彼らは，初発膠芽腫に扮ける放射線療法と TMZ との併用治療群と放射線治療のみを行った群との間で の TMZ 治療効果を解析し，その情報と MGMT プロモー ターのメチル化との関連性を検討した結果, MGMT プロ モーターメチル化のある症例では治療反応性が良好であ ることを報告した。彼らの使ったメチル化特異的 PCR (methylation-specific PCR) は, 容易かつ非常に再現性の 高い手法であり，しかも理論的に TMZ 耐性と直結でき る因子である MGMT の臨床的重要性が強調されたの で, MGMT プロモーターメチル化とグリオーマの予後あ るいは治療反応性との関連性については多くの研究者に 注目され，MGMTこそが TMZ 化学療法の耐性因子であ るかのような論調も広まった。しかし，その後 MGMT プロモーターメチル化のある腫瘍は，使用する化学療法 剤の種類にかかわらず予後良好であり，また MGMT と はまったく理論的な関係がないはずの放射線治療に関し ても同様に予後良好であることが幾つかの臨床研究にお いて発表されており，生物学的な意味では MGMT は DNA アルキル化剂に対する耐性因子であるものの, 臨床 的には MGMT プロモーターメチル化は TMZ による治 療反応性よりも広い範囲での予後を反映したものである との考光が有力になりつつある29)。すなわち MGMT フ 口モーターメチル化は，全般的に DNA 障害性治療に対 する感受性が高い腫愓の特徴であり，悪性グリオーマの 化学療法感受性は多因子によって決定されていると考光
られる。この考えによ机ば, MGMT プロモーター非メチ ル化グリオーマにおいても TMZ 抵抗性の克服は MGMT の不活化のみでは成功しないことも考えられ, 治 療成績の改善のためには他の重要な因子の探索が不可欠 である、実際，MGMTの作用を抑制する日的で $\mathrm{O}^{6}$-benzylguanine（MGMT の分解を促進する）を TMZ に併用 した臨床試験や，TMZ の持続的投与（休薬期間を短くす る）を行った臨床試験の結果からは, 正常細胞への TMZ の効果増強は現れても, 予想したような腫瘍に対する治 療効果の改善には至らないとの結果が得られ ${ }^{15) 18)}$, MGMT のみが TMZ 耐性を規定する因子ではないこと は明白となっている。まとめると，確かに MGMT プロ モーターメチル化は TMZ の作用に直接関係することが 理論的に説明される因子ではあるものの, 実際には第 1 染色体 $\mathrm{p}$ 腕・第 19 染色体 $\mathrm{q}$ 腕共欠失（1p/19q loss）や イソクエン酸脱水酵素 1 (isocitrate dehydrogenase 1: IDH1）変異と同樣に予後（治療反応性）良好な腫瘍群を 特徴づける遺伝学的マーカーであるとの考光が主流にな りつつある2126).

実際には MGMT 以外にも TMZ 耐性に大きく関与す ると考元られる因子が存在し，その一つが DNA ミス マッチ修復系（DNA mismatch repair, MMR）である.

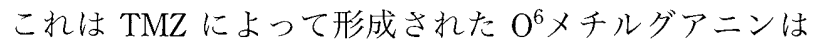
それ自体では致死的な DNA 損傷にはならず，これに引 き続いて起こる GT ミスマッチ形成チミン除去を不毛 に繰り返す（futile repair cycle）ことが細胞毒性につなが るためである。したがって, DNA ミスマッチ修復機構が 機能していない細胞においては TMZ の毒性は発揮され ないことになり，実際にそのような腫瘍は血球系腫瘍や 大腸癌などの癌腫で存在が確認されている。これに対し て，一般的にグリオーマでは MMRが正常に機能してい ることが多いとされているが1)，これらの知見は主に初 発腫瘍に捛ける解析結果から得られたものであり, DNA アルキル化剤を用いた治療後の再発腫瘍では MMR 関 連因子の変異や発現低下がまれではないことも報告され ている3).

また悪性腫瘍において補助療法抵抗性に関与すること が知られている因子として Akt キナーゼ系10)がある。 Akt は受容体型チロシンキナーゼからの情報が phosphatidyl inositol-3 kinase（PI3K）を介して伝達されること で活性化するが，この経路に対して負の制御（活性抑制） を行う PTEN ホスファターゼは, 悪性グリオーマにおい ては不活化が多く認められ，悪性グリオーマ，特に膠芽 腫においては Akt キナーゼ系の機能六進が起きている. ただし Akt キナーゼ系の詳細な機能解析はまだ十分で 


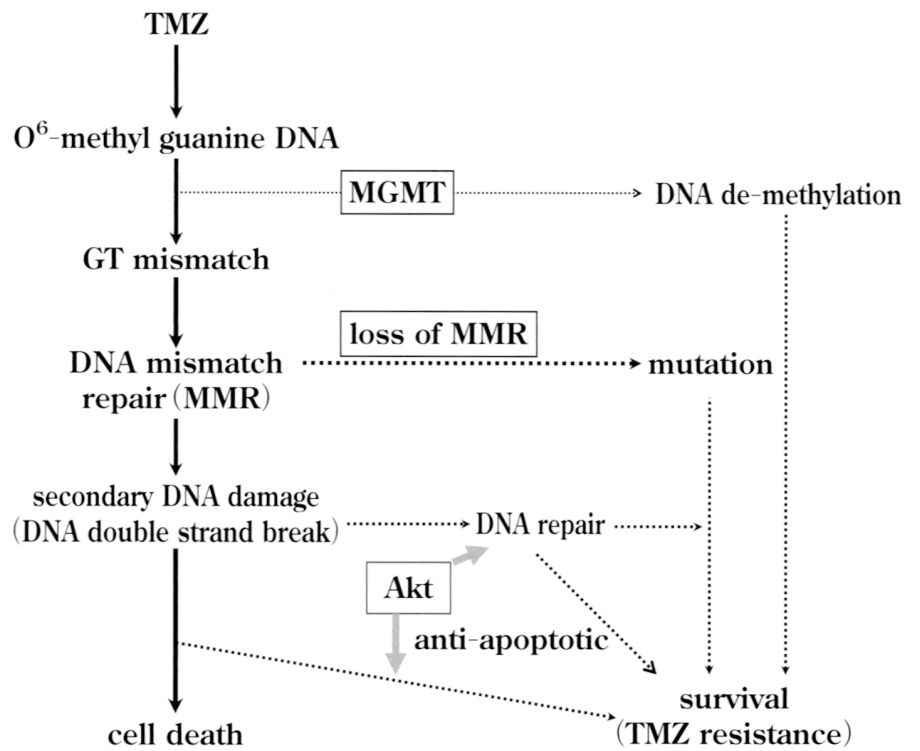

Fig. 1 Schematic illustration of temozolomide's action

Pathways related to temozolomide resistance are shown in a dotted line.

TMZ : temozolomide, MGMT: $\mathrm{O}^{6}$-methylguanine-DNA methyltransferase,

GT : guanine-thymine, MMR : mismatch repair

Table 1 List of the molecular targeted compounds used in clinical trials against malignant gliomas

\begin{tabular}{|c|c|c|c|}
\hline Compound & Target molecule & Property & Target expression in glioma \\
\hline Gefinitib $^{6) 20)}$ & EGFR & small molecule inhibitor & positive to amplified \\
\hline Erlotinib ${ }^{17) 27)}$ & EGFR & small molecule inhibitor & positive to amplified \\
\hline Vatalanib $^{2)}$ & VEGFRs & small molecule inhibitor & negative \\
\hline Bevacizumab $^{13) 22)}$ & VEGFR & monoclonal antibody & $\begin{array}{l}\text { (indirect effect on tumor growth) } \\
\text { negative } \\
\text { (indirect effect on tumor growth) }\end{array}$ \\
\hline Enzastaurin $^{12)}$ & protein kinase $\mathrm{C} \beta$ & small molecule inhibitor & positive, activated? \\
\hline Imatinib $^{28)}$ & PDGFR, $c^{-k i t}$ & small molecule inhibitor & positive \\
\hline Cilengitide $^{19)}$ & integrin $\alpha_{\mathrm{v}} \beta_{3}$ & small molecule inhibitor & positive \\
\hline Temsirolimus $^{7)}$ & mTOR & small molecule inhibitor & positive, activated \\
\hline Rapamycin ${ }^{4}$ & mTOR & small molecule inhibitor & positive, activated \\
\hline
\end{tabular}

EGFR : epidermal growth factor receptor, VEGFR: vascular endothelial growth factor receptor, PDGFR: plateletderived growth factor receptor, mTOR: mammalian target of rapamycin

はなく, 腫瘍生物学の重要な課題の一つである。上記の まとめを図に示す (Fig. 1).

\section{新規薬娮への展望}

TMZ を中心とした化学療法剤による治療に限界があ ることはすでに明らかであるが，もともと遺伝子の不安 定性をもちながら異常増殖するという腫瘍細胞の特性を 考えれば，グリオーマも DNA 損傷に対する防御機構を もっていることは容易に想像できる。腫瘍の薬剤治療は 正常細胞と腫瘍細胞の特徴の差異を利用して効果を上げ ることを目標とするが，従来の化学療法はその中の細胞 分裂速度を利用したものであった。ところがこの戦略の
限界が明らかになると, 細胞分裂以外の点での腫瘍細胞の 特性を利用しようとする考えが注目されるようになった。 いわゆる分子標的治療 (molecular target therapy) がそれ である.現在までに悪性グリオーマに対する臨床試験の 行われた薬剤を Table 1 に示す2)4)6)7)12)13)17)19)20)22)27)28).

最初に注目されたのは，グリオーマにおいて増幅して いることがよく知られている上皮成長因子受容体 (epidermal growth factor receptor：EGFR）を標的とした治療 である. EGFR は細胞分裂に対して正の制御（促進）を するとともに，細胞保護的（抗アポトーシス）作用をも $つ$ phosphatidylinositol-3 kinase (PI3K)-Akt 系の細胞内 情報伝達系の調節にも関与するため，グリオーマの増殖 性や治療抵抗性において中心的役割をもつのではないか 
と考えられたことがあった。したがって多臓器の癌治療 において EGFR 阻害剤（gefitinib，erlotinib）が臨床導入 されると，これをグリオーマ治療にも応用しようという 考えで臨床試験が行われたが，米国で行われた多施設共 同臨床研究において，これらの分子標的薬は期待どおり の結果は示さず6)17)20), 有効症例は EGFRvIII（常時活性 型の変異型) を発現し，かつ PTEN に変異を認めない症 例に限られた ${ }^{14)}$. また欧州での臨床研究ではAktの活性 化の少ない症例で有効性が認められたとの報告もされ た27)が，いずれの場合も EGFR の増幅は治療効果と相関 しないという結果が得られ，EGFR 阻害剤による治療は グリオーマに拈いてはごく一部の症例でのみ効果が期待 されうるという結論が得られた。これに対して EGFR 阻 害剂と TMZ の併用は TMZ 単独の治療よりも有効であ るとの研究結果も報告され, 分子標的治療と化学療法の 併用がグリオーマの薬剤治療の分野に新しい展開をもた らす可能性が示唆された ${ }^{17)}$ が, EGFR シグナルと TMZ 感受性との間には何の関連性も示されておらず，効果の 発現機序は不明である。

次に注目された抗 VEGF 単クローン抗体薬剤 bevacizmabについては，すでに本誌で解説されているので，そ ちらを参照されたい ${ }^{11)}$. 結論としては, bevacizmabもこ れまでの治療と比べて有意な生存延長効果は示していな いということである。ただし，一時的なものではあって も画像検査上の造影剂増強域や脳浮腫の縮小と臨床症状 の改善をもたらすという点では bevacizmab は有用な薬 剤であり，使用状況によってはグリオーマ患者にとって 大きな助けとなりうるものである。

Bevacizmab と同様に腫瘍血管に作用する薬剤として cilentitide という integrin $\alpha_{v} \beta_{3}$ 阻害薬があるが， integrin $\alpha_{\mathrm{v}} \beta_{3}$ はグリオーマに掞いても発現して細胞外 マトリックスから刺激を受けて細胞遊走能などに関わる 情報を仲介するとされている5)。したがって本来 cilentitiude にはグリオーマ細胞を殺傷する能力はないものと 考えられるが，興味深いことに cilentitiude と TMZの併 用は TMZ 単独治療と比べて有意に再発までの期間を延 長することが報告された ${ }^{25)}$ ，ところが同時にこの効果は MGMT プロモーターのメチル化と関連していたことも 示され，化学療法が有効でない症例では分子標的治療の 効果の上乗せが期待できないことを示唆している。

\section{おわりに}

今後のグリオーマ薬剤治療において分子標的薬の役割 が増えることは十分予想される。しかし，現状では単剤
で十分な抗腫痬効果を示す分子標的薬は開発されておら ず，臨床的な效果を期待するためには TMZ を中心とし た化学療法を併用することが現実的である。グリオーマ の細胞生物学的特性についての治験の蓄積が, 薬剤治療 における突破口につながるものと考えられる。

\section{文 献}

1) Alonso M, Hamelin R, Kim M, Porwancher K, Sung T, Parhar P, Miller DC, Newcomb EW: Microsatellite instability occurs in distinct subtypes of pediatric but not adult central nervous system tumors. Cancer Res $\mathbf{6 1}: 2124-2128$, 2001.

2) Brandes AA, Stupp R, Hau P, Lacombe D, Gorlia T, Tosoni A, Mirimanoff RO, Kros JM, van den Bent MJ : EORTC study 26041-22041: Phase I / II study on concomitant and adjuvant temozolomide (TMZ) and radiotherapy (RT) with PTK787/ZK222584 (PTK/ZK) in newly diagnosed glioblastoma. Eur J Cancer $\quad 46: 348-354,2010$.

3) Cahill DP, Levine KK, Betensky RA, Codd PJ, Romany CA, Reavie LB, Batchelor TT, Futreal PA, Stratton MR, Curry WT, Iafrate AJ, Louis DN: Loss of the mismatch repair protein MSH6 in human glioblastomas is associated with tumor progression during temozolomide treatment. Clin Cancer Res $13: 2038-2045,2007$.

4) Cloughesy TF, Yoshimoto K, Nghiemphu P, Brown K, Dang J, Zhu S, Hsueh T, Chen Y, Wang W, Youngkin D, Liau L, Martin N, Becker D, Bergsneider M, Lai A, Green R, Oglesby T, Koleto M, Trent J, Horvath S, Mischel PS, Mellinghoff IK, Sawyers CL: Antitumor activity of rapamycin in a Phase I trial for patients with recurrent PTEN-deficient glioblastoma. PLoS Med 5: e8, 2008.

5) D'Abaco GM, Kaye AH: Integrins : molecular determinants of glioma invasion. $J$ Clin Neurosci 14:10411048,2007

6) Franceschi E, Cavallo G, Lonardi S, Magrini E, Tosoni A, Grosso D, Scopece L, Blatt V, Urbini B, Pession A, Tallini $G$, Crinò L, Brandes AA: Gefitinib in patients with progressive high-grade gliomas: A multicentre phase II study by Gruppo Italiano Cooperativo di Neuro-Oncologia (GICNO). Br J Cancer 96:1047-1051, 2007.

7) Galanis E, Buckner JC, Maurer MJ, Kreisberg JI, Ballman K, Boni J, Peralba JM, Jenkins RB, Dakhil SR, Morton RF, Jaeckle KA, Scheithauer BW, Dancey J, Hidalgo M, Walsh DJ; North Central Cancer Treatment Group: Phase II trial of temsirolimus (CCI-779) in recurrent glioblastoma multiforme: a North Central Cancer Treatment Group Study. J Clin Oncol 23: 5294-5304, 2005.

8) Hegi ME, Diserens AC, Gorlia T, Hamou MF, de Tribolet N, Weller M, Kros JM, Hainfellner JA, Mason W, Mariani L, Bromberg JEC, Hau P, Mirimanoff RO, Cairncross G, Janzer RC, Stupp R: MGMT gene silencing and benefit from temozolomide in glioblastoma. $N$ Engl J Med $\mathbf{3 5 2}$ : 997-1003, 2005.

9) Hirose Y, Kreklau EL, Erickson LC, Berger MS, Pieper $\mathrm{RO}$ : Delayed repletion of 06-methylguanine-DNA methyltransferase resulting in failure to protect the human glioblastoma cell line SF767 from temozolomide-induced cytotoxicity. J Neurosurg 98: 591-598, 2003.

10) Hirose Y, Katayama M, Mirzoeba OK, Berger MS, Pieper 
RO : Akt activation suppresses Chk2-mediated, methylating agent-induced G2 arrest and protects from temozolomide-induced mitotic catastrophe and cellular senescence. Cancer Res 65:4861-4869, 2005.

11）廣瀬雄一：悪性グリオーマの集学的治療に向けての生物 学. 脳外誌 19:880-886, 2010.

12) Kreisl TN, Kotliarova S, Butman JA, Albert PS, Kim L, Musib L, Thornton D, Fine HA: A phase I/II trial of enzastaurin in patients with recurrent high-grade gliomas. Neuro Oncol 12:181-189, 2010.

13) Lai A, Tran A, Nghiemphu PL, Pope WB, Solis OE, Selch M, Filka E, Yong WH, Mischel PS, Liau LM, Phuphanich S, Black K, Peak S, Green RM, Spier CE, Kolevska T, Polikoff J, Fehrenbacher L, Elashoff R, Cloughesy T: Phase II study of bevacizumab plus temozolomide during and after radiation therapy for patients with newly diagnosed glioblastoma multiforme. J Clin Oncol 29: 142148, 2011.

14) Mellinghoff IK, Wang MY, Vivanco I, Haas-Kogan DA, Zhu S, Dia EQ, Lu KV, Yoshimoto K, Huang JH, Chute DJ, Riggs BL, Horvath S, Liau LM, Cavenee WK, Rao PN, Beroukhim R, Peck TC, Lee JC, Sellers WR, Stokoe D, Prados M, Cloughesy TF, Sawyers CL, Mischel PS: Molecular determinants of the response of glioblastomas to EGFR kinase inhibitors. $N$ Engl J Med 353:20122024, 2005.

15) Neyns B, Tosoni A, Hwu WJ, Reardon DA: Dose-dense temozolomide regimens: Antitumor activity, toxicity, and immunomodulatory effects. Cancer 116:2868-2877, 2010.

16) Osoba D, Braba M, YungWKA, Prados A: Health-related quality of life in patients treated with temozolomide versus procarbazine for recurrent glioblastoma multiforme. $J$ Clin Oncol 18: 1481-1491, 2000.

17) Prados MD, Chang SM, Butowski N, DeBoer R, Parvataneni R, Carliner H, Kabuubi P, Ayers-Ringler J, Rabbitt J, Page M, Fedoroff A, Sneed PK, Berger MS, McDermott MW, Parsa AT, Vandenberg S, James CD, Lamborn KR, Stokoe D, Haas-Kogan DA: Phase II study of erlotinib plus temozolomide during and after radiation therapy in patients with newly diagnosed glioblastoma multiforme or gliosarcoma. J Clin Oncol 27:579-584, 2009.

18) Quinn JA, Jiang SX, Reardon DA, Desjardins A, Vredenburgh JJ, Rich JN, Gururangan S, Friedman AH, Bigner DD, Sampson JH, McLendon RE, Herndon JE 2nd, Walker A, Friedman HS: Phase II trial of temozolomide plus $\mathrm{O}^{6}$ benzylguanine in adults with recurrent, temozolomideresistant malignant glioma. J Clin Oncol 27: 1262-1267, 2009.

19) Reardon DA, Fink KL, Mikkelsen $T$, Cloughesy $T F$, O'Neill A, Plotkin S, Glantz M, Ravin P, Raizer JJ, Rich KM, Schiff D, Shapiro WR, Burdette-Radoux S, Dropcho EJ, Wittemer SM, Nippgen J, Picard M, Nabors LB : Randomized phase II study of cilengitide, an integrin-targeting arginine-glycine-aspartic acid peptide, in recurrent glioblastoma multiforme. J Clin Oncol 26:5610-5617, 2008.

20) Rich JN, Reardon DA, Peery T, Dowell JM, Quinn JA, Penne KL, Wikstrand CJ, Van Duyn LB, Dancey JE, McLendon RE, Kao JC, Stenzel TT, Rasheed BKA, TourtUhlig SE, Herndon JE, Vredenburgh JJ, Sampson JH, Friedman AH, Bigner DD, Friedman HS: Phase II trial of gefitinib in recurrent glioblastoma. J Clin Oncol 22:133$142,2004$.

21) Rivera AL, Pelloski CE, Gilbert MR, Colman H, De La Cruz C, Sulman EP, Bekele BN, Aldape KD : MGMT promoter methylation is predictive of response to radiotherapy and prognostic in the absence of adjuvant alkylating chemotherapy for glioblastoma. Neuro Oncol 12:116$121,2010$.

22) Scott BJ, Quant EC, McNamara MB, Ryg PA, Batchelor TT, Wen PY : Bevacizumab salvage therapy following progression in high-grade glioma patients treated with VEGF receptor tyrosine kinase inhibitors. Neuro Oncol 12: 603-607, 2010.

23) Stupp R, Mason WP, van den Bent MJ, Weller M, Fisher $\mathrm{B}$, Taphoorn MJ, Belanger K, Brandes AA, Marosi C, Bogdahn U, Curschmann J, Janzer RC, Ludwin SK, Gorlia T, Allgeier A, Lacombe D, Cairncross JG, Eisenhauer E, Mirimanoff RO; European Organisation for Research and Treatment of Cancer Brain Tumor and Radiotherapy Groups; National Cancer Institute of Canada Clinical Trials Group: Radiotherapy plus concomitant and adjuvant temozolomide for glioblastoma. $N$ Engl J Med 352:987996, 2005.

24) Stupp R, Hegi ME, Mason WP, van den Bent MJ, Taphoorn MJ, Janzer RC, Ludwin SK, Allgeier A, Fisher B, Belanger K, Hau P, Brandes AA, Gijtenbeek J, Marosi C, Vecht CJ, Mokhtari K, Wesseling P, Villa S, Eisenhauer E, Gorlia T, Weller M, Lacombe D, Cairncross JG, Mirimanoff RO; European Organisation for Research and Treatment of Cancer Brain Tumour and Radiation Oncology Groups; National Cancer Institute of Canada Clinical Trials Group: Effects of radiotherapy with concomitant and adjuvant temozolomide versus radiotherapy alone on survival in glioblastoma in a randomised phase III study: 5 -year analysis of the EORTC-NCIC trial. Lancet Oncol 10: 459-466, 2009.

25) Stupp R, Hegi ME, Neyns B, Goldbrunner R, Schlegel U, Clement PM, Grabenbauer GG, Ochsenbein AF, Simon M, Dietrich PY, Pietsch T, Hicking C, Tonn JC, Diserens AC, Pica A, Hermisson M, Krueger S, Picard M, Weller M: Phase I / II a study of cilengitide and temozolomide with concomitant radiotherapy followed by cilengitide and temozolomide maintenance therapy in patients with newly diagnosed glioblastoma. J Clin Oncol 28:2712-2718, 2010.

26) van den Bent MJ, Dubbink HJ, Sanson M, van der LeeHaarloo CR, Hegi M, Jeuken JW, Ibdaih A, Brandes AA, Taphoorn MJ, Frenay M, Lacombe D, Gorlia T, Dinjens WN, Kros JM: MGMT promoter methylation is prognostic but not predictive for outcome to adjuvant PCV chemotherapy in anaplastic oligodendroglial tumors: A report from EORTC Brain Tumor Group Study 26951. J Clin Oncol 27: 5881-5886, 2009.

27) van den Bent MJ, Brandes AA, Rampling R, Kouwenhoven $\mathrm{MC}$, Kros JM, Carpentier AF, Clement PM, Frenay $M$, Campone M, Baurain JF, Armand JP, Taphoorn MJ, Tosoni A, Kletzl H, Klughammer B, Lacombe D, Gorlia T: Randomized phase II trial of erlotinib versus temozolomide or carmustine in recurrent glioblastoma: EORTC brain tumor group study 26034. J Clin Oncol 27: 1268-1274, 2009.

28) Wen PY, Yung WK, Lamborn KR, Dahia PL, Wang Y, Peng B, Abrey LE, Raizer J, Cloughesy TF, Fink K, Gilbert M, 
Chang S, Junck L, Schiff D, Lieberman F, Fine HA, Mehta M, Robins HI, DeAngelis LM, Groves MD, Puduvalli VK, Levin V, Conrad C, Maher EA, Aldape K, Hayes M, Letvak L, Egorin MJ, Capdeville R, Kaplan R, Murgo AJ, Stiles C, Prados MD: Phase I/II study of imatinib mesylate for recurrent malignant gliomas: North American Brain Tumor Consortium Study 99-08. Clin Cancer Res 12: 4899-4907, 2006.
29) Wick W, Hartmann C, Engel C, Stoffels M, Felsberg J, Stockhammer F, Sabel MC, Koeppen S, Ketter R, Meyermann R, Rapp M, Meisner C, Kortmann RD, Pietsch T, Wiestler OD, Ernemann U, Bamberg M, Reifenberger G, von Deimling A, Weller M: NOA-04 randomized phase III trial of sequential radiochemotherapy of anaplastic glioma with procarbazine, lomustine, and vincristine or temozolomide. J Clin Oncol 27: 5874-5880, 2009.

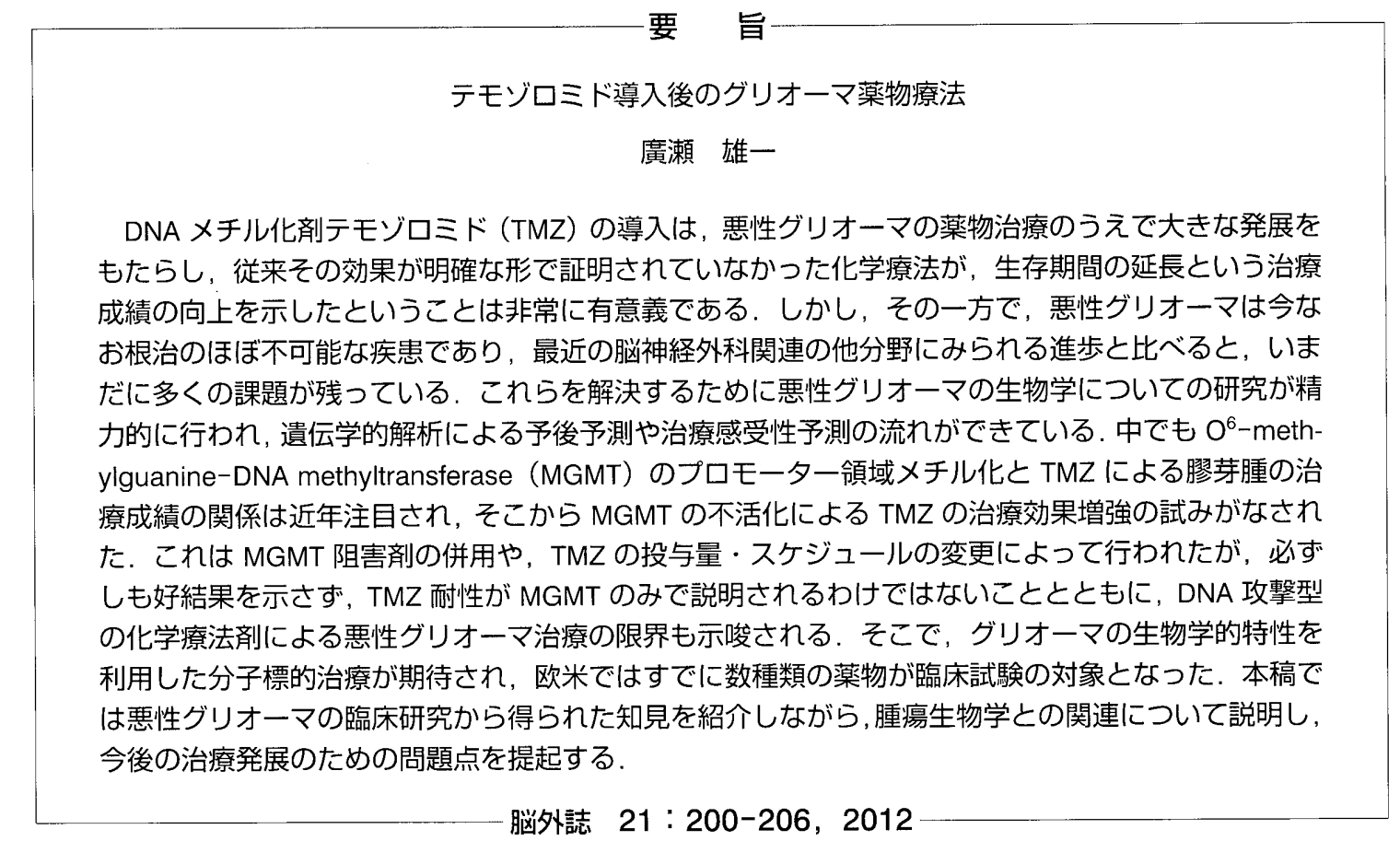

